\section{Availability simulation and analysis
of armored face conveyor machine \\ Availability simulation and analysis
of armored face conveyor machine in longwall mining}

Rudarsko-geološko-naftni zbornik

(The Mining-Geology-Petroleum Engineering Bulletin) UDC: 622.2

DOI: 10.17794/rgn.2021.2.7

Original scientific paper

\author{
Raziye Norouzi Masir'; Mohammad Ataei²; Farhang Sereshki; Ali Nouri Qarahasanlou ${ }^{4}$ \\ ${ }^{1}$ Faculty of Mining, Petroleum and Geophysics Engineering, Shahrood University of Technology, Shahrood, Iran. \\ Raziye_Norouzi@shahroodut.ac.ir,ORCID:0000-0001-8646-7717 \\ ${ }^{2}$ Faculty of Mining, Petroleum and Geophysics Engineering, Shahrood University of Technology, Shahrood, Iran. \\ Ataei@shahroodut.ac.ir, ORCID: 0000-0002-7016-8170 \\ ${ }^{3}$ Faculty of Mining, Petroleum and Geophysics Engineering, Shahrood University of Technology, Shahrood, Iran. \\ farhang-sereshki@shahroodut.ac.ir \\ ${ }^{4}$ Faculty of Technical \& Engineering, Imam Khomeini International University, Qazvin, Iran. \\ Ali_Nouri@eng.ikiu.ac.ir,ORCID:0000-0003-1302-7176
}

\begin{abstract}
Since coal mining production systems are very complex, repairing equipment is expensive. If a system failure occurs, it will cause disturbances such as inoperable equipment, reduced operating time, increased production costs, and reduced equipment performance. Therefore, it is necessary to consider the availability of the coal mining industry more than ever. For this purpose, the Armored Face Conveyor (AFC) machine failure data was gathered over a period of 29 months from the Tabas Coal Mine. Descriptive statistics, trends, and serial correlation tests of the data were calculated. Then, the system's mean and point availability were simulated. Based on the results, the mean availability (all events) and point availability (all events) at $360000 \mathrm{~h}$ are $96 \%$ and $95 \%$, respectively. The mean time to first failure (MTTFF) of the AFC machine was about 23.61 h. The ReliaSoft Failure Criticality Index, ReliaSoft Downing Event Criticality Index, and ReliaSoft Downtime Criticality Index electrical equipping have the largest effect, whereas the main drive subsystem is the least important. Analysis showed that availability has a direct correlation to activity management and improvements in the quality, efficiency, and the product extraction.
\end{abstract}

Keywords:

Armored Face Conveyor (AFC), reliability, maintainability, Availability Simulation

\section{Introduction}

In the coal mining industry, there are different systems in connection with each other that can be considered as subsystems of the production system. Among the production systems in longwall mines, the Armored Face Conveyor (AFC) machine is one of the main subsystems of the mine that directly affects the production capacity of the underground mine. When systems fail, they cause problems, such as shorter life cycles of systems, decreased product delivery times, decreased level of product customization, decreased product quality, and increased production costs (Beeson and Andrews, 2003; Naghiloo et al., 2011; Dai et al., 2015; Ataei and Norouzi Masir, 2020; Hoseinie et al., 2020). On the other hand, each failure is followed by a process called maintenance and repair (net). This situation hinders workers' safety and productivity. As previously mentioned, failure, shutdown, and the inability to restore the

Corresponding author: Raziye Norouzi Masir

Raziye_Norouzi@shahroodut.ac.ir systems to the pre-failure condition results in irreparable damage, thus a higher grade of reliability for mining equipment is required. Also, each subsystem affects the total system performance indexes of the whole production line (Rahimdel et al., 2013). Thus, it is necessary for the performance indexes of each subsystem to be analyzed for in order to determine how each subsystem functions.

Since the late 1998s, the Norwegian oil and gas industry has studied the idea of the relationship between performance indexes at the component level and the relationship of these components with each other within the system as well as their effects on the system's deliverability, i.e. production assurance, which was presented and became a standard in later years. In this approach, the relationship between Throughput Capacity and Dependability (De) is expressed. Dependability was first defined in 1990 by the International Electronics Commission (IEC) as a criterion for describing Reliability, Availability, and Maintainability (RAM) parameters.

However, among these three parameters, availability is the parameter that affects the whole production line in 
Table 1: Summary of research regarding the availability, reliability and maintainability of mining equipment

\begin{tabular}{|c|c|c|c|c|}
\hline Study type & Study origin & Case & Major objective/outcome & Reference \\
\hline $\begin{array}{l}\text { Survey and } \\
\text { case study }\end{array}$ & Sweden & $\begin{array}{l}\text { Kiruna Iron Ore } \\
\text { Mine }\end{array}$ & $\begin{array}{l}\text { Discussion on reliability analysis of a load-haul- } \\
\text { dump machine (LHD) production system. }\end{array}$ & $\begin{array}{l}\text { Kumar and Huang, } \\
\text { (1993) }\end{array}$ \\
\hline $\begin{array}{l}\text { Survey and } \\
\text { case study }\end{array}$ & Canada & $\begin{array}{l}\text { Sudbury mining } \\
\text { region in Ontario }\end{array}$ & $\begin{array}{l}\text { Investigation of how to assess major maintenance to } \\
\text { determine equipment availability of an LHD, and } \\
\text { also trends in the LHD operating characteristics. }\end{array}$ & $\begin{array}{l}\text { Vagenas et al., } \\
\text { ( 1997) }\end{array}$ \\
\hline Survey & General & & $\begin{array}{l}\text { Summarized relevant methods for reliability and } \\
\text { availability analysis of a Caterpillar and determined } \\
\text { data requirements and information sources. }\end{array}$ & $\begin{array}{l}\text { Hall and Daneshmend, } \\
\text { (2003a) }\end{array}$ \\
\hline $\begin{array}{l}\text { Survey and } \\
\text { case study }\end{array}$ & $\begin{array}{l}\text { Chilean } \\
\text { Andes }\end{array}$ & gold mine & $\begin{array}{l}\text { Analyses over a period of fifteen months covering } \\
\text { maintenance historical data with the maintainability } \\
\text { method of mobile haulage equipment fleets such as } \\
\text { LHD and underground haul trucks. }\end{array}$ & $\begin{array}{l}\text { Hall and Daneshmend, } \\
\text { (2003b) }\end{array}$ \\
\hline $\begin{array}{l}\text { Survey and } \\
\text { case study }\end{array}$ & Iran & $\begin{array}{l}\text { Jajarm Bauxite } \\
\text { Mine }\end{array}$ & $\begin{array}{l}\text { Evaluation of the reliability, and maintainability of a } \\
\text { crushing plant with different subsystems to identify } \\
\text { total downtime, breakdown frequency. }\end{array}$ & $\begin{array}{l}\text { Barabady, } \\
(\mathbf{2 0 0 5 )}\end{array}$ \\
\hline $\begin{array}{l}\text { Survey and } \\
\text { case study }\end{array}$ & & $\begin{array}{l}\text { Garp Linyitleri } \\
\text { Isletmesi }\end{array}$ & $\begin{array}{l}\text { Study of the maintainability of the mechanical } \\
\text { systems of electric cable shovels applying the unit } \\
\text { root and serial correlation tests for the independent } \\
\text { and identically distributed (iid) assumption test. }\end{array}$ & $\begin{array}{l}\text { Elevli et al. } \\
(2008)\end{array}$ \\
\hline $\begin{array}{l}\text { Survey and } \\
\text { case study }\end{array}$ & Iran & $\begin{array}{l}\text { Jajarm Bauxite } \\
\text { Mine }\end{array}$ & $\begin{array}{l}\text { Description of reliability and availability analysis of } \\
\text { crushing plant number } 3 \text {. }\end{array}$ & $\begin{array}{l}\text { Barabady and Kumar, } \\
(2008)\end{array}$ \\
\hline $\begin{array}{l}\text { Survey and } \\
\text { case study }\end{array}$ & Canada & $\begin{array}{l}\text { underground } \\
\text { hard rock mine } \\
\text { in the Sudbury } \\
\text { area at Ontario }\end{array}$ & $\begin{array}{l}\text { Examination of maintenance and reliability analysis } \\
\text { of a fleet of LHD vehicles in an underground hard } \\
\text { rock mine. }\end{array}$ & $\begin{array}{l}\text { Vayenas and } W u, \\
(2009)\end{array}$ \\
\hline Survey & General & & $\begin{array}{l}\text { Development of a new optimization and simulation } \\
\text { modelling framework based upon the expected } \\
\text { efficiency of a truck-shovel machine. }\end{array}$ & $\begin{array}{l}\text { Mena et al. } \\
(2013)\end{array}$ \\
\hline $\begin{array}{l}\text { Survey and } \\
\text { case study }\end{array}$ & Norway & Svea Coal Mine & $\begin{array}{l}\text { Presenting the reliability and availability assessment } \\
\text { of a main conveyor machine. }\end{array}$ & $\begin{array}{l}\text { Furuly et al. } \\
\text { (2014) }\end{array}$ \\
\hline \begin{tabular}{|l|} 
Survey \\
\end{tabular} & General & & $\begin{array}{l}\text { Assessment of the availability of a studied shearer } \\
\text { machine and the structure of registered breaks in its } \\
\text { work. }\end{array}$ & $\begin{array}{l}\text { Brodny et al. } \\
(2017)\end{array}$ \\
\hline $\begin{array}{l}\text { Survey and } \\
\text { case study }\end{array}$ & Iran & $\begin{array}{l}\text { Sungun copper } \\
\text { mine }\end{array}$ & $\begin{array}{l}\text { A procedure to identify a suitable reliability and } \\
\text { maintainability model for a dump truck and loader } \\
\text { based upon trend tests such as the NHPP, HNHPP, } \\
\text { and HPP. }\end{array}$ & $\begin{array}{l}\text { Razzaghzadeh et al. } \\
(2019)\end{array}$ \\
\hline Survey & General & & $\begin{array}{l}\text { Evaluation of reliability, maintainability, and } \\
\text { availability of a tunnel boring machine (TBM) } \\
\text { operating in mixed ground conditions by means of } \\
\text { Markov chains. }\end{array}$ & $\begin{array}{l}\text { Kumar Agrawal et al. } \\
\text { (2019) }\end{array}$ \\
\hline $\begin{array}{l}\text { Survey and } \\
\text { case study }\end{array}$ & Iran & $\begin{array}{l}\text { Sarcheshmeh } \\
\text { copper mine }\end{array}$ & $\begin{array}{l}\text { Modelling and simulation of the reliability of rotary } \\
\text { drilling systems. }\end{array}$ & $\begin{array}{l}\text { Rahimdel et al. } \\
(\mathbf{2 0 2 0 )}\end{array}$ \\
\hline Survey & General & & $\begin{array}{l}\text { Modelling the reliability and maintainability based } \\
\text { upon the reliability-based method to estimate the } \\
\text { mean time between failures (MTBF) and mean and } \\
\text { time to repair (MTTR) for a shovel-dumper system. }\end{array}$ & $\begin{array}{l}\text { Harish Kumar et al. } \\
(\mathbf{2 0 2 0 )}\end{array}$ \\
\hline
\end{tabular}

a mining equipment subsystem. In this regard, the performance of each subsystem must be evaluated to determine how they affect the availability of the whole production unit (Rahimdel et al., 2013; Furuly et al., 2013). In general, availability is very useful and suitable for organizing, planning, improving, deciding, and simulating the quality of the products of mining equipment.
As a whole, since early 1993, availability studies in the mining industry have been offered. Since then, different availability studies in the mining industry have been completed. However, literature review of availability in mining reveals that the most studied mining equipment refers to the load-haul-dump machine (LHD), loader, truck-shovel, conveyor, hydraulic shovel, shear- 


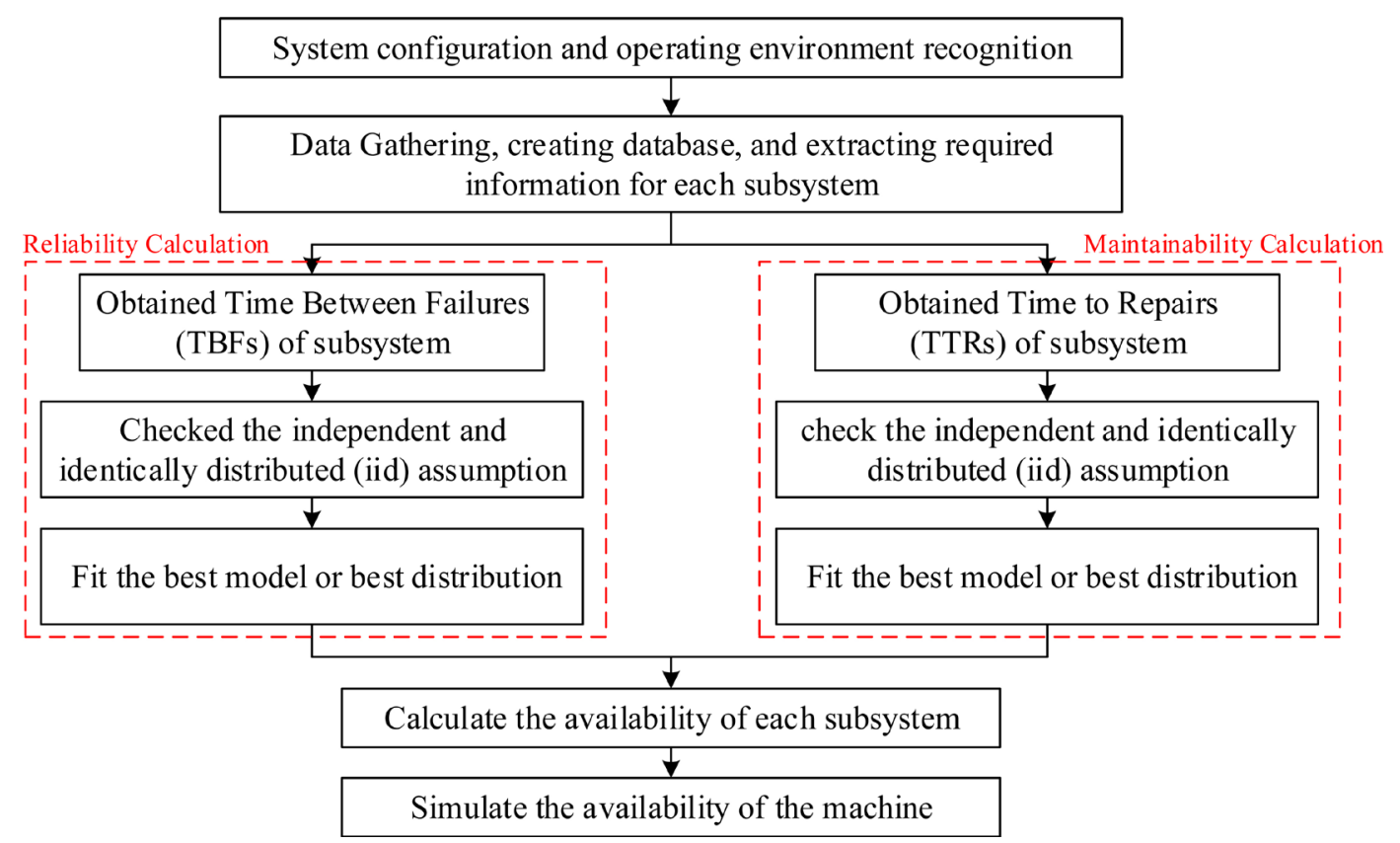

Figure 1: The framework of the methodology used to evaluate availability analysis and simulation.

er, crushing plant, horizontal transport of excavated material to the shaft zone, and cable shovel study by ignoring other mining equipment, such as the AFC machine.

As previously mentioned, nowadays, when systems fail, they cause a lot of problems (such as shorter life cycles of systems, decreased product delivery times, decreased level of product customization, decreased product quality, and increased production costs) and these problems affect production systems and mining equipment. Table 1 presents a summary of studies with research on availability, reliability, and maintainability in the mining industry.

In the existing literature, many sources only analyse reliability, which includes only the operating times of the system, while we can analyse the full time when the downtime (maintainability) can be included in the analysis. Also, none of these studies have simulated the system's mean and point availability. Most importantly, despite the conducted research to analyse availability in mining equipment, in the literature, no studies have been carried out on an AFC. Most of the research is related to open-pit mines, and less research has been done on underground coal mines.

The rest of this paper is outlined in two general parts. In part 2, the methodology, collecting data are briefly described. In Section 3, a simulation of the availability of an AFC machine in longwall mining was performed.

\section{Methodology}

The present study aims to calculate mean and point availability to simulate the availability of an AFC machine. To this end, an approach for simulating was de- veloped. Figure 1 illustrates the framework for the proposed approach.

As shown in Figure 1, the identification of a system is regarded as the first step to determine s-independent components/subsystems of the system; all subsystems are repairable; which will be in one of two possible situations: operational or failure; Failure and repair properties of subsystems. In the following, reliability, and maintainability of every subsystem are analysed and the function is fitted. Afterwards, the availability of each subsystem is estimated using the mean time between failure (MTBF) and mean time to repair (MTTR) values, and finally, the simulate availability is calculated.

\subsection{Reliability}

From the mid-1960s to the late 1980 s, reliability assessment methods have been presented as suitable tools for the organizing, scheduling, and act of automatic and complex mining machines. The reliability was defined by IEV (191-02-06) as "the ability of an item to perform a required function under given conditions for a given time interval" (IEC 60050, 2014). This approach is the probability that failure cannot be prevented fully but can accomplish its considered function(s) without fail for a specified time under considered situations. The mathematical description of reliability is estimated as follow (Equation 1) (Dhillon, 2008):

$$
\mathrm{R}(\mathrm{t})=1-\mathrm{F}(\mathrm{t})=1-\int_{0}^{t} f(x) d x
$$

Where:

$\mathrm{R}(\mathrm{t})$ - the reliability at time $\mathrm{t}$,

$\mathrm{F}(\mathrm{t})$ - the cumulative failure distribution function,

$\mathrm{f}(\mathrm{x})$ - the failure probability density function. 
The reliability characteristics of equipment can be specified by assessing the time between failures (TBF) data. Failures occurring in repairable systems are the result of discrete events occurring over time. These processes are often called stochastic point processes. In general, there are three techniques for reliability evaluation of repairable systems based on the following (Hoseinie et al., 2012):

a) Renewal Process (RP)

b) Homogeneous Poisson Process (HPP)

c) Non-homogeneous Poisson process (NHPP).

The renewal process model is based on the basic mathematical assumption that the times between events are independent and identically circulated (iid). The homogeneous Poisson process, in addition to the renewal process assumptions, also adds the assumption that periods follow exponential distribution. This process is not suitable to analyze the data of repairable systems that have a trend in the failure data due to degradation or improvement of the system. However, NHPP is suitable for modeling if there is a trend in the failure data. If there is no trend and no serial correlation in the data, the failure data are iid, and the classical statistical technique is a useful tool for modeling such as log logistic, lognormal, and Weibull (Pandey et al., 2018; Rahimdel et al., 2013).

\subsection{Maintainability}

In the early 1990s, this method was introduced for the mining field that a special role in preserving the quantity and the quality of products, and it ought to be controlled at a determined level. Maintainability engineering is done to minimize downtime which is introduced by (IEV 191-02-07) as "the ability of an item under given conditions of use, to be retained in, or restored to, a state in which it can perform a required function, when maintenance is performed under given conditions and using stated procedures and resources" (IEC 60050, 2014). In general, it is indicated in terms of a Mean-Time-To-Repair (MTTR). The other factor to be considered is the maximum time repair, which can be defined for every one of the diverse levels of maintenance (Barabady and Kumar, 2007). In parametric technique, if $T$ is a random variable, which donates the Time-To-Repair (TTR) of an unsuccessful sub-system, the mathematical definition of maintainability will be equal to Equation 2:

$$
\mathrm{M}(\mathrm{t})=\int_{0}^{t} m(t) d t
$$

Where:

$M(t)$ - the maintainability at time $t$ or the cumulative repair distribution function,

$m(t)$ - the repair density function.

Generally, there are models for estimating maintainability, such as classical methods or covariate-based models like the proportional repair model. A classical maintainability technique is divided into methods, like the time distribution or time model of the event records or the historical time data. This model is suitable for manufacturers because it causes a lot of production, and also it is possible to provide a general overview of item behaviour. The five steps related to the approach method are as follows (Hoseinie et al., 2012):

- Step 1: Determining TTR for each sub-system.

- Step 2: Testing the data for the autonomous and identically distributed (iid) assumption to appropriate the data to the theoretical probability distributions or models.

- Step 3: Creating the theoretical probability distributions to the TTR data utilizing the iid assumption and a time-dependent model like the power law process (PLP) model for data-reject-it.

- Step 4: Analysing the goodness-of-fit of a theoretical probability distribution to the data.

- Step 5: Calculating the maintainability of every subsystem and the entire system utilizing the system configuration relationships.

Since the classical methods are suitable for considering the TTR (or total TTR) variable as the only variable of interest but a covariate-based model is useful to address the individual maintainability of a system in dynamic operative environment conditions. To enter the effects of environmental conditions in the repair estimation, the proportional repair model (PRM) and the stratified cox regression model (SCRM) are used.

\subsection{Availability}

The concept of availability is now widely developed. There are various definitions and schools of thought of availability in literature. One such definition on availability was released by Stapelberg at the Handbook of Reliability, Availability, Maintainability, and Safety in Engineering Design in 2009 as "the probability that a system is operating satisfactorily at any point in time when used under stated conditions, where the time considered includes the operating time and the active repair time" (Stapelberg, 2009). Generally, availability in engineering design has its roots in designing for reliability and maintainability, in which an 'up-down' method is considered, mainly from the design's systems-level to its equipment level (i.e. assembly level), and constraints on systems performance are specified. As illustrated in the following Figure 2 (Stapelberg, 2009).

Where:

TPM - total preventive maintenance,

TCM - total corrective maintenance,

ALDT - administrative and logistics downtime.

By definition, availability can be said to be somewhat flexible and mainly based upon types of failures that one can consider in the analysis. By and large, there are several taxonomies of availability, like instantaneous or 


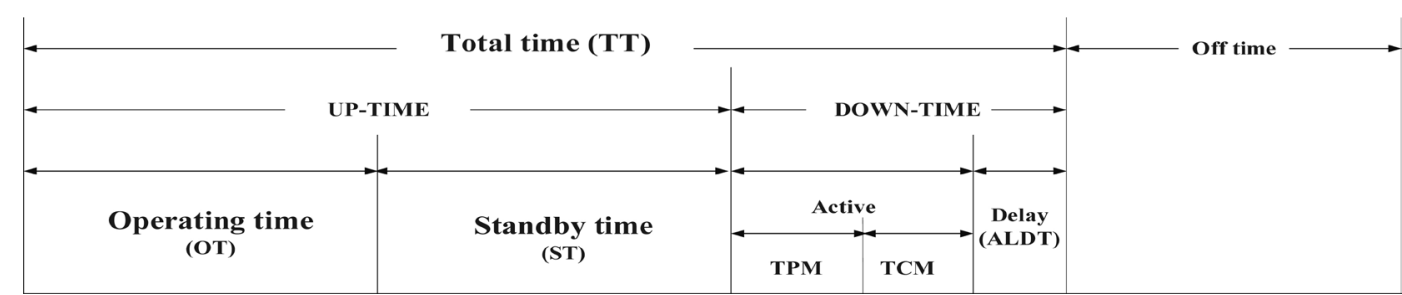

Figure 2: Breakdown of the total system's equipment time (DoD 3235.1-H 1982) (Stapelberg, 20o9).

point availability, average uptime availability (or mean availability), steady-state availability, inherent availability, achieved availability, and availability of operational that in this paper used point availability, average uptime availability. The following are described.

\subsubsection{Instantaneous or Point Availability}

Point availability is the probability that a system or component will be active (up and down) at each random time, t. This method is very similar to the function of reliability which expresses the probability a system will function at a certain time, t. On the contrary reliability, the point availability criterion includes maintainability information. Point availability is generated by Equation 3 (Li, 2012):

$$
\mathrm{A}(\mathrm{t})=\mathrm{R}(\mathrm{t})+\int_{0}^{t} R(t-u) m(u) d u
$$

Where:

$A(t)$ - point availability, if (i) the item functioned properly from 0 to $t$; the probability of this happening is $\mathrm{R}(\mathrm{t})$; or (ii) the system has functioned properly since the last repair at time $\mathrm{u}, 0$ $<\mathrm{u}<\mathrm{t}$,

$\mathrm{m}(\mathrm{u})$ - the renewal density function of the system, the probability of this condition is $\int_{0}^{t} R(t-u) m(u) d u$.

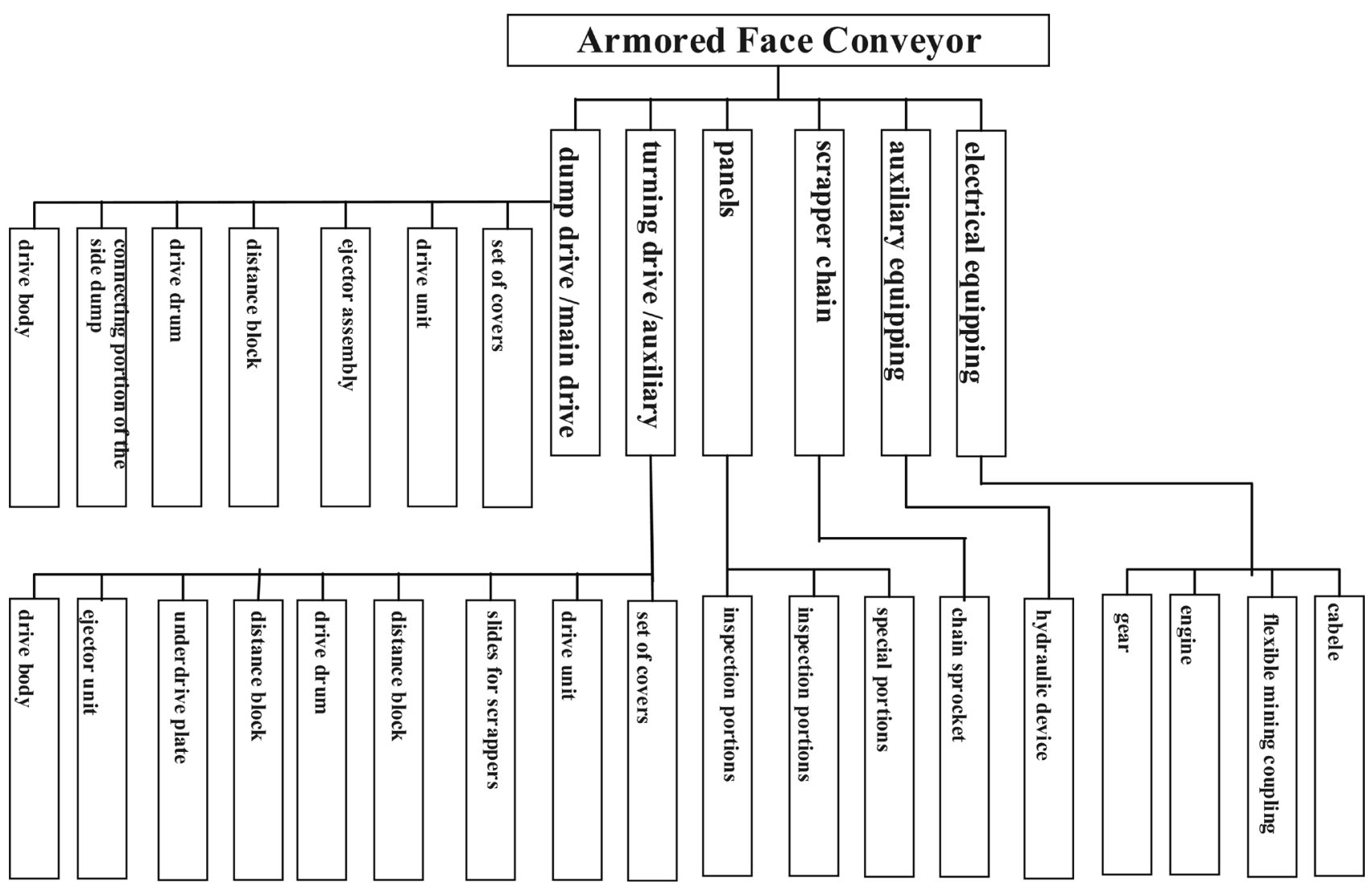

Figure 3: Major and minor subsystems of an AFC.

\begin{tabular}{|lllll}
\hline dump drive /main drive & turning drive /auxiliary \\
\hline
\end{tabular}

Figure 4: Reliability block diagram of an AFC. 


\subsubsection{Average Uptime Availability (or Mean Availability)}

The mean availability is the proportion of time during a mission or time that the system is available for usage. It demonstrates the mean value of the point availability function over the time $(0, t)$ and is created by (Equation 4) $(\mathbf{L i}, 2012)$ :

$$
\overline{A(t)}=\frac{1}{t} \int_{0}^{t} A(u) d u
$$

\section{Case study: longwall AFC machine}

The application of proposed availability analysis and simulation was examined in a real case in Iran. For this aim, the Armored Face Conveyor (AFC) Rybnik 850 machine of the Tabas longwall coal mine was considered as a case study. This machine is used for the transportation of material from faces with a longitudinal inclination up to \pm 35 degrees. This conveyor is equipped with components enabling its cooperation with coal shearers with the Eicotrack chainless haulage machine. These conveyors working in seams of longitudinal inclination above 12 degrees have their drives fixed on traveling bolting devices protecting them from sliding and providing their proper positioning. The route of the conveyor is suitable for assembling the guards connected with the roof support and protecting the conveyor against sliding during operation and flitting. Conveyors working in longitudinal inclination between 15 to 25 degrees and a height below $1.7 \mathrm{~m}$ are equipped with extended gates protecting the operators against hits by coal pieces. Inseams with longitudinal inclination above 25 degrees and height above $1.7 \mathrm{~m}$, the protection of operators should be provided by the mechanized roof support. Conveyors working in seams in lateral crosswise inclination up to 10 degrees have their panels fitted with one side shearer running device whereas those working in seams of crosswise inclination from 10 to 25 degrees have their panels equipped with double side shearer running device /shearer guiding cage rests from caving and sidewall. In Figure 3, major and minor subsystems of an AFC is shown. Since failure in any system or subsystem leads to machine breakdown, all seven systems and subsystems are considered serially. Figure 4, shows the reliability block diagram of the major systems of an AFC.

\subsection{Data Gathering}

At this stage, data can be gathered from diverse sources, for example, the diurnal activities and production reports of supervisors and the maintenance reports of the systems, archival records, existing statistics, documentation, direct observation, and interview. All events (repairs) of subsystems of the systems were chosen from the databank. The available data pertains to a coal cutting operation in two whole panels of the mine that was gathered over a period of 29 months. The data consists of 286 failures and the related time for repairs. Among the subsystems, there were no scrapper chain and auxiliary system failures.

\subsection{Reliability Analysis of AFC}

As can be seen in Figure 1, after preparing data, validation of the assumption of the independent and identically distributed (iid) nature of the TBF data should all be verified. As mentioned earlier, there are ways to calculate reliability, to assess the hypothesis of the iid of the data, and for this purpose, trend and correlation tests are used. To perform the trend test, through the analytical technique, which is presented in the book of American Army (MIL-Hdbk-189), the Laplace test (LA), MannKendall, and Anderson-Darling test were applied. To calculate these tests and data analysis and find the best distributions, we used Minitab version 19 from ReliaSoft.

In Table 2, the analytical results of the trend test of the subsystems at a significance level of $\alpha=0.05$ are shown. For this aim, at first, the Laplace trend test and the military handbook test are considered for each one of the homogeneous sub-systems. If the p-values of these tests are more than $\alpha$ null, the hypothesis for both are not rejected, the dataset is considered to be non-trended. If p-values of these tests are less than $\alpha$ null, the hypothesis for both are accepted and the Mann-Kendall test for the sub-systems will be applied. If one of the two tests pvalues are less than, the null hypothesis is not rejected for this test, and Anderson's Darling test is employed. If p-values of Anderson's Darling test less than $\alpha$, the Mann-Kendall test for the sub-systems will be used.

As it can be concluded from Table 2 the p-values of TBFs are less than $\alpha$ for turning drive/auxiliary and, panels, whereas the $p$-values of TBFs are more than $\alpha$ for dump drive/main drive and electrical equipping; as a result, the null hypothesis was not accepted for turning drive/auxiliary, panels, but the null hypothesis was accepted for dump drive /main drive and electrical equipping.

Also, it is noted from Figure 5. The graphical trend test for the dump drive/main drive subsystem. This graph indicates whole conformity to the results of the analytic tests. Calculations about the acception or rejection of the null hypothesis of 'no autocorrelation', by the autocorrelation function $(\mathrm{ACF})$ at $95 \%$ confidence level, were made utilizing auto-correlograms (see Figure 5b). In this graph, ACF values are denoted by columns and $95 \%$ confidence bounds are denoted by upper and lower dashes. As it can be concluded, the ACF column on time lag 1 is (dump drive/main drive $=0.16$ ) and is placed in the confidence level. Thus, the null hypothesis is not rejected.

Based on Figure 5, the data are not correlated or dependent, because the data points are not along a straight line. 
Table 2: Analytical trend test results for TBFs of AFC subsystems.

\begin{tabular}{|c|c|c|c|c|c|c|}
\hline \multirow{2}{*}{ Subsystem } & \multirow{2}{*}{ Trend test } & \multirow{2}{*}{ MIL-Hdbk-189 } & \multirow{2}{*}{ Laplace's } & \multirow{2}{*}{ Anderson-Darling } & \multicolumn{2}{|c|}{ Mann-Kendall } \\
\hline & & & & & Convex & Concave \\
\hline \multirow[t]{3}{*}{ Dump drive/main drive } & Test Statistic & 256.39 & -0.83 & 1.38 & & \\
\hline & P-Value & 0.446 & 0.407 & 0.209 & & \\
\hline & analytic test result & \multicolumn{3}{|l|}{ no trend } & & \\
\hline \multirow[t]{3}{*}{ Turning drive /auxiliary } & Test Statistic & 287.25 & -2.06 & 4.04 & & \\
\hline & P-Value & 0.073 & 0.039 & 0.008 & 0.9997 & 0.0002 \\
\hline & analytic test result & \multicolumn{3}{|l|}{ trend } & & \\
\hline \multirow[t]{3}{*}{ Panels } & Test Statistic & 42.58 & 1.95 & 4.67 & & \\
\hline & P-Value & 0.086 & 0.051 & 0.004 & 0.9846 & 0.0153 \\
\hline & analytic test result & \multicolumn{3}{|l|}{ trend } & & \\
\hline \multirow[t]{3}{*}{ Electrical equipping } & Test Statistic & 144.71 & 1.50 & 1.88 & & \\
\hline & P-Value & 0.064 & 0.133 & 0.107 & & \\
\hline & analytic test result & \multicolumn{3}{|l|}{ no trend } & & \\
\hline
\end{tabular}

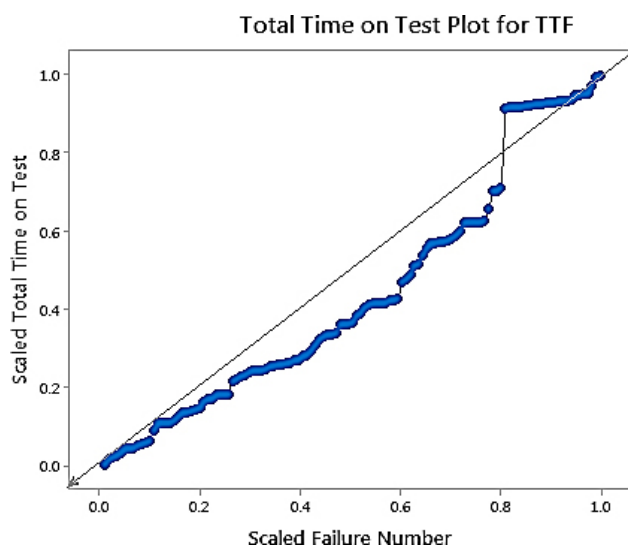

(a)

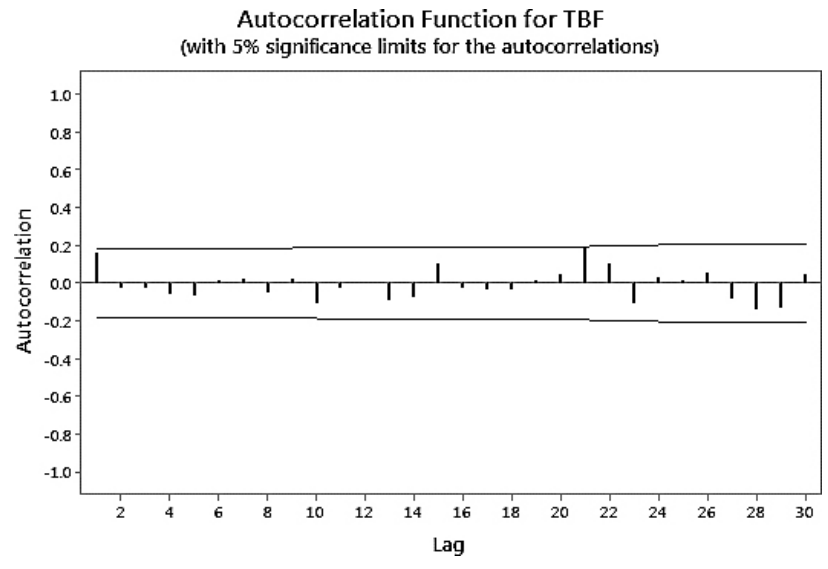

(b)

Figure 5: Trend (a) and serial correlation (b) test result for TBFs of dump drive /main drive subsystem.

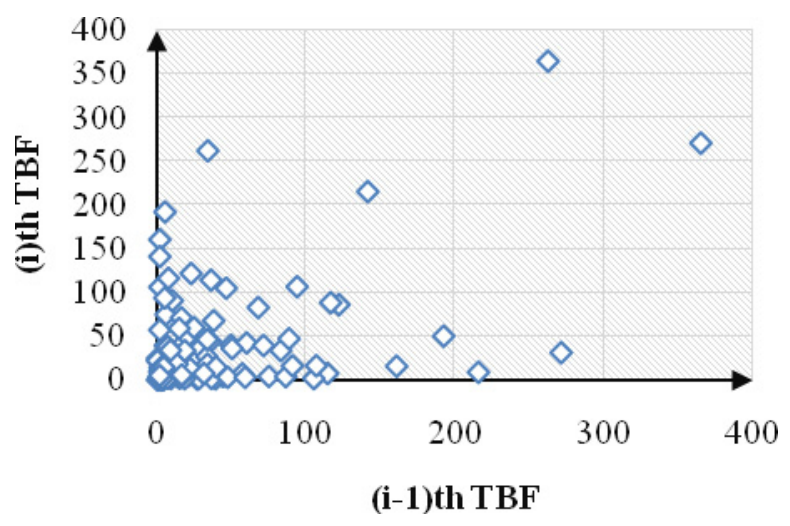

Figure 6: The results of graphical serial correlation tests of dump drive/main drive subsystem.

An important issue to consider in conjunction with the test is that the data must be timed because data sorting causes convergence (Kumar and Klefsjö, 1992 and Hall and Daneshmend, 2003 a). As shown in Figure 6, there is no correlation in the TBFs of the various subsystems.
According to the results of the trend test and serial correlation indicate that the dump drive/main drive and electrical equipping are free from trends and serial correlation. Thus, the data of the mentioned subsystems are independent and identically distributed (iid) whereas, there are no trends and no correlation to the TBF data set for the two turning drive/auxiliary, and panels, so, the NHPP technique is suitable for the reliability modelling of these subsystems. As mentioned before, the PLP, which is a specific form of the NHPP, was chosen for assessing the reliability above-mentioned subsystems. Table 3 represents the result of data analysis, best-fit distributions, and parameter estimation for all subsystems.

\subsection{Maintainability Analysis of AFC}

As previously noted, we need time data. Therefore, after preparing the data, the maintainability characteristics of the mining equipment can be investigated by the assessment of time to repair (TTR) data sets. Also, it is necessary to investigate the validation of the assumption of the independent and identically distributed (iid) na- 
ture of the TTR data of all items. In this regard, there are ways to estimate maintainability, in order to analyse the hypothesis of iid of the data, trend and correlation tests are used. To perform the trend test, the analytical technique, which is described in the book of the American Army (MIL-Hdbk-189), Laplace test (LA), AndersonDarling test were applied. To calculate these tests and data analysis and finding the best distributions, we used Minitab version 19 from ReliaSoft. The steps used in the

Table 3: Best-fit distribution for strata, covariates, and MTTF calculation for failure data.

\begin{tabular}{|l|l|l|}
\hline Subsystem & Best-fit & Parameter \\
\hline $\begin{array}{l}\text { Dump drive/main } \\
\text { drive }\end{array}$ & Lognormal & $\begin{array}{l}\text { Shape: } 0.863346 \\
\text { Scale: } 17.2389\end{array}$ \\
\hline $\begin{array}{l}\text { Turning drive } \\
\text { /auxiliary }\end{array}$ & PLP & $\begin{array}{l}\text { Shape: } 1.79327 \\
\text { Scale: } 723.060\end{array}$ \\
\hline Panels & PLP & $\begin{array}{l}\text { Shape: } 1.45603 \text { Scale: } \\
\text { 461.245 }\end{array}$ \\
\hline $\begin{array}{l}\text { Electrical } \\
\text { equipping }\end{array}$ & $\begin{array}{l}\text { 3-Parameter } \\
\text { Weibull }\end{array}$ & $\begin{array}{l}\text { Shape: 0.687974, Scale: } \\
\text { 45.8784, Thres: 1.26019 }\end{array}$ \\
\hline
\end{tabular}

previous section for analysing these tests were also used in this section.

As can be concluded from Table 4, the p-values of MTTR are more than $\alpha$; as a result, the null hypothesis was accepted. Figure 7 shows the graphical trend of the test results for the dump drive/main drive subsystem. As can be seen Figure 7 (b), the ACF column on time lag for dump drive/main drive is 0.30 and is placed above the confidence level. Thus, the null hypothesis is accepted.

As displayed in Figure 7 and Table 4 the assumption of iid is not suitable for subsystems; therefore, the NHPP or PLP technique will be useful for the explanation of failures and repair behavior in running time. According to Table 5, the best-fit distributions and their corresponding parameters are displayed for TTR data.

\subsection{Availability Analysis and Simulation of AFC}

When you consider both reliability and maintainability, furthermore criterion is required for the probability that the system is operational at a certain time. This criterion is availability. In other words, it is considered that

Table 4: Analytical trend test results for MTTRs of AFC subsystems.

\begin{tabular}{|c|c|c|c|c|}
\hline Subsystem & Trend test & MIL-Hdbk-189 & Laplace's & Anderson-Darling \\
\hline \multirow[t]{3}{*}{ Dump drive /main drive } & Test Statistic & 270.15 & -0.52 & 0.62 \\
\hline & P-Value & 0.278 & 0.606 & 0.626 \\
\hline & Analytic test result & \multicolumn{3}{|l|}{ no trend } \\
\hline \multirow[t]{3}{*}{ Turning drive /auxiliary } & Test Statistic & 76.90 & -1.94 & 1.96 \\
\hline & P-Value & 0.140 & 0.053 & 0.097 \\
\hline & Analytic test result & \multicolumn{3}{|l|}{ no trend } \\
\hline \multirow[t]{3}{*}{ Panels } & Test Statistic & 56.77 & -0.51 & 0.59 \\
\hline & P-Value & 0.811 & 0.608 & 0.661 \\
\hline & Analytic test result & \multicolumn{3}{|l|}{ no trend } \\
\hline \multirow[t]{3}{*}{ Electrical equipping } & Test Statistic & 185.30 & 0.91 & 0.79 \\
\hline & P-Value & 0.536 & 0.365 & 0.491 \\
\hline & Analytic test result & \multicolumn{3}{|l|}{ no trend } \\
\hline
\end{tabular}

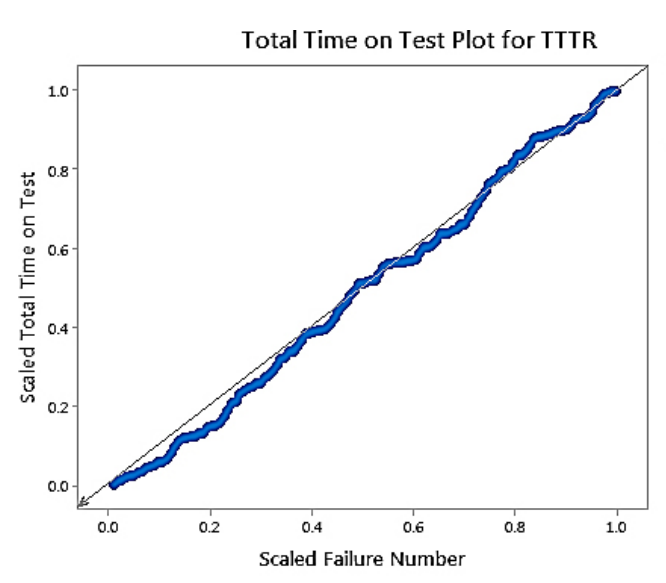

(a)

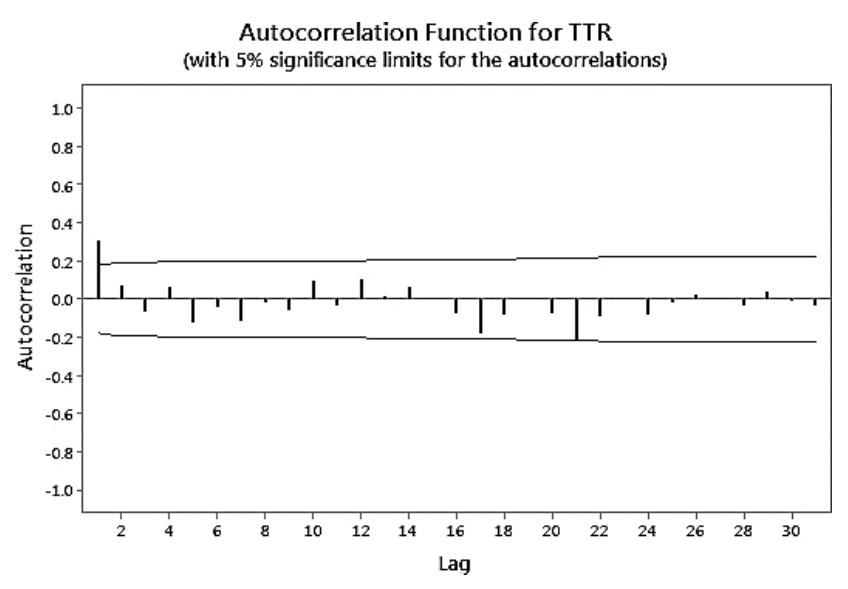

(b)

Figure 7: Trend (a) and serial correlation (b) test result for TTRs AFC dump drive/main drive subsystem. 
Table 5: Best-fit distribution for strata, covariates, and MTTR calculation for failure data.

\begin{tabular}{|l|c|l|}
\hline Subsystem & Best-fit & Parameter \\
\hline \multirow{2}{*}{ Dump drive /main drive } & \multirow{2}{*}{ PLP } & Shape: 0.917995 \\
\cline { 3 - 3 } & & Scale: 1.67056 \\
\hline \multirow{2}{*}{ Turning drive /auxiliary } & \multirow{2}{*}{ PLP } & Shape: 0.806263 \\
\cline { 3 - 3 } & & Scale: 1.43394 \\
\hline
\end{tabular}

\begin{tabular}{|l|c|l|}
\hline Subsystem & Best-fit & Parameter \\
\hline \multirow{2}{*}{ Panels } & \multirow{2}{*}{ PLP } & Shape: 1.09222 \\
\cline { 3 - 3 } & & Scale: 4.22456 \\
\hline \multirow{2}{*}{ Electrical equipping } & \multirow{2}{*}{ PLP } & Shape: 1.07932 \\
\cline { 3 - 3 } & & Scale: 1.66787 \\
\hline
\end{tabular}

the system is operating properly when it is requested for utilization.

The AFC machine is in action for $8 \mathrm{~h}$ per each 8 -h operational shift. The production action has three shifts daily and operates 30 days monthly. The whole operation of the production system is $720 \mathrm{~h}(=3 \times 8 \times 30)$ per month.

The simulation was done for 29 months or about $21000 \mathrm{~h}$ utilizing BlockSim software from ReliaSoft in every subsystem of the AFC, which results in over 1,000 simulations for this system; the results are outlined in

Table 6. The results show that the mean availability of the AFC system at $21000 \mathrm{~h}$ is $96 \%$. Mean time to first failure (MTTFF) of the AFC system was about $23.61 \mathrm{~h}$.

The plots of the mean availability are displayed in Figure 8. It shows that the mean availability of the system dropped significantly during the first hours, but it increased again and reached a constant value.

The system point results, as demonstrated in Table 7 , denote the items defined in the prior sections. These are computed and returned at different points in time, based

Table 6: Simulation results for the AFC machine at $21000 \mathrm{~h}$.

\begin{tabular}{|l|l|l|l|l|l|l|l|l|}
\hline Machine & $\begin{array}{l}\text { Mean } \\
\text { availability } \\
\text { (all events) }\end{array}$ & $\begin{array}{l}\text { Standard deviation } \\
\text { (mean availability) }\end{array}$ & $\begin{array}{l}\text { Point } \\
\text { availability } \\
\text { (all events) }\end{array}$ & Reliability & MTTFF & $\begin{array}{l}\text { MTBF } \\
\text { (total time) }\end{array}$ & $\begin{array}{l}\text { MTBF } \\
\text { (uptime) }\end{array}$ & $\begin{array}{l}\text { Uptime } \\
\text { (h) }\end{array}$ \\
\hline AFC & 0.960 & 0.013 & 0.95 & 0 & 23.605 & 46.204 & 44.357 & 960.009 \\
\hline
\end{tabular}

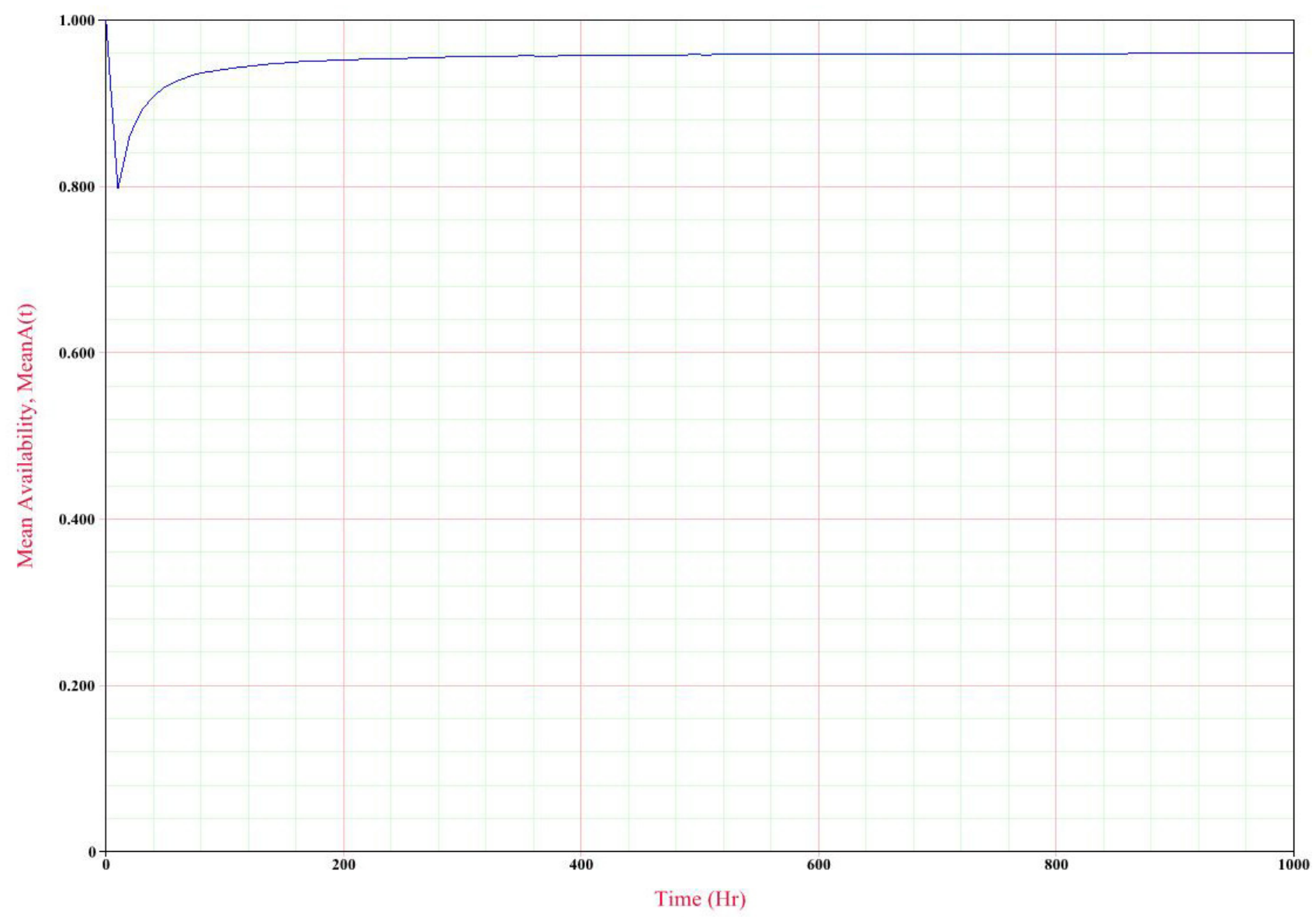

Figure 8: Mean System Availability (o-100o). 
Table 7: System point results.

\begin{tabular}{|l|c|c|c|c|c|c|c|}
\hline Time (Hr) & $\mathbf{A}(\mathbf{t})$ & $\mathbf{R}(\mathbf{t})$ & $\mathbf{( 1 - A ( t ) )} \%$ & $\mathbf{( 1 - R ( t ) )} \%$ & Mean A(t) & A(t[i] - t[i-1]) & System Failures(t) \\
\hline 10 & 0.893 & 0.36 & 10.7 & 64 & 0.797047 & 0.797047 & 1.216 \\
\hline 20 & 0.939 & 0.269 & 6.1 & 73.1 & 0.861342 & 0.925638 & 1.616 \\
\hline$\cdot$ & $\cdot$ & $\cdot$ & $\cdot$ & $\cdot$ & $\cdot$ & $\cdot$ & $\cdot$ \\
$\cdot$ & $\cdot$ & $\cdot$ & $\cdot$ & $\cdot$ & $\cdot$ & $\cdot$ & $\cdot$ \\
\hline 1000 & 0.95 & 0 & 5 & 100 & 0.960009 & 0.955279 & 21.643 \\
\hline
\end{tabular}

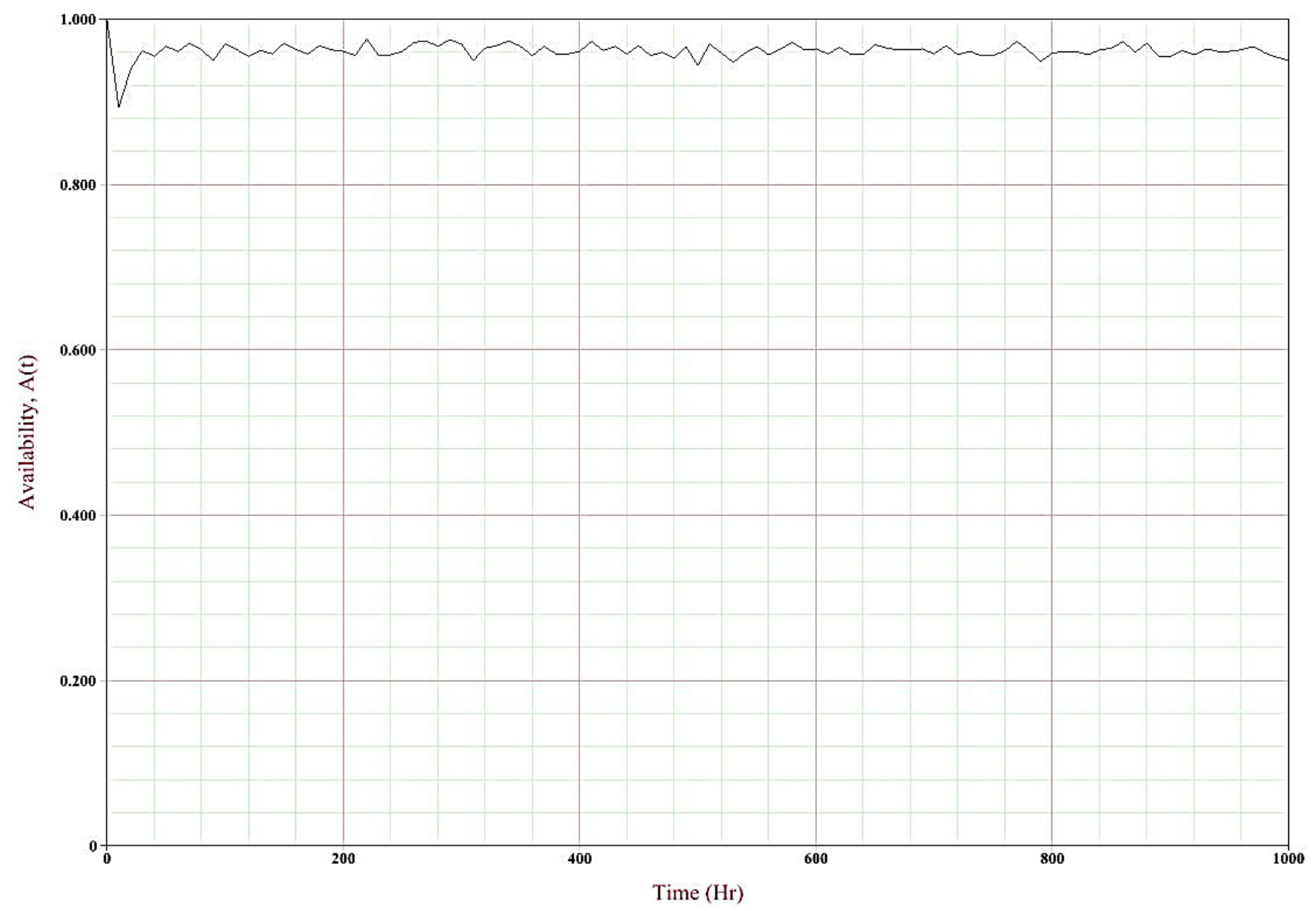

Figure 9: Point System Availability.

on the number of intervals selected. The number of intervals shown is based on the set increments. In Figure 9, the number of increments set was 1000, which implies that the results should be displayed every hour. The results shown in Table 7 are for 10 increments, or shown every 100 hours. The availability point of the AFC machine $1000 \mathrm{Hr}$ is also shown in Figure 9.

The system and block Up-Down of the entire AFC subsystems are plotted in Figure 10. Generally, system Uptime displays the average time the system was up and operational while system Downtime indicates the average time the system was down for corrective maintenance actions (CM) only. In other words, this approach is used to illustrate the sequence of events, a single block with a failure, and a repair distribution. To achieve the desired result, this process is repeated many times and the total Downtime (Hr) was 39.99.

To show the percentage of times that a failure of this component lead the failure of a subsystem, the percentage of times that a downing event of the block caused the subsystems to go into downtime, and relative index is an indication of the contribution of the block to the subsystems downtime, the ReliaSoft Failure Criticality Index (this is a relative index showing the percentage of times that a failure of this metric lead a system to go downtime (RS FCI)) was used, along with the ReliaSoft Downing Event Criticality Index (this is a relative index indicating the percentage of times which a downing event of the block caused the system failure (RS DECI)), and the ReliaSoft Downtime Criticality Index (this is a 


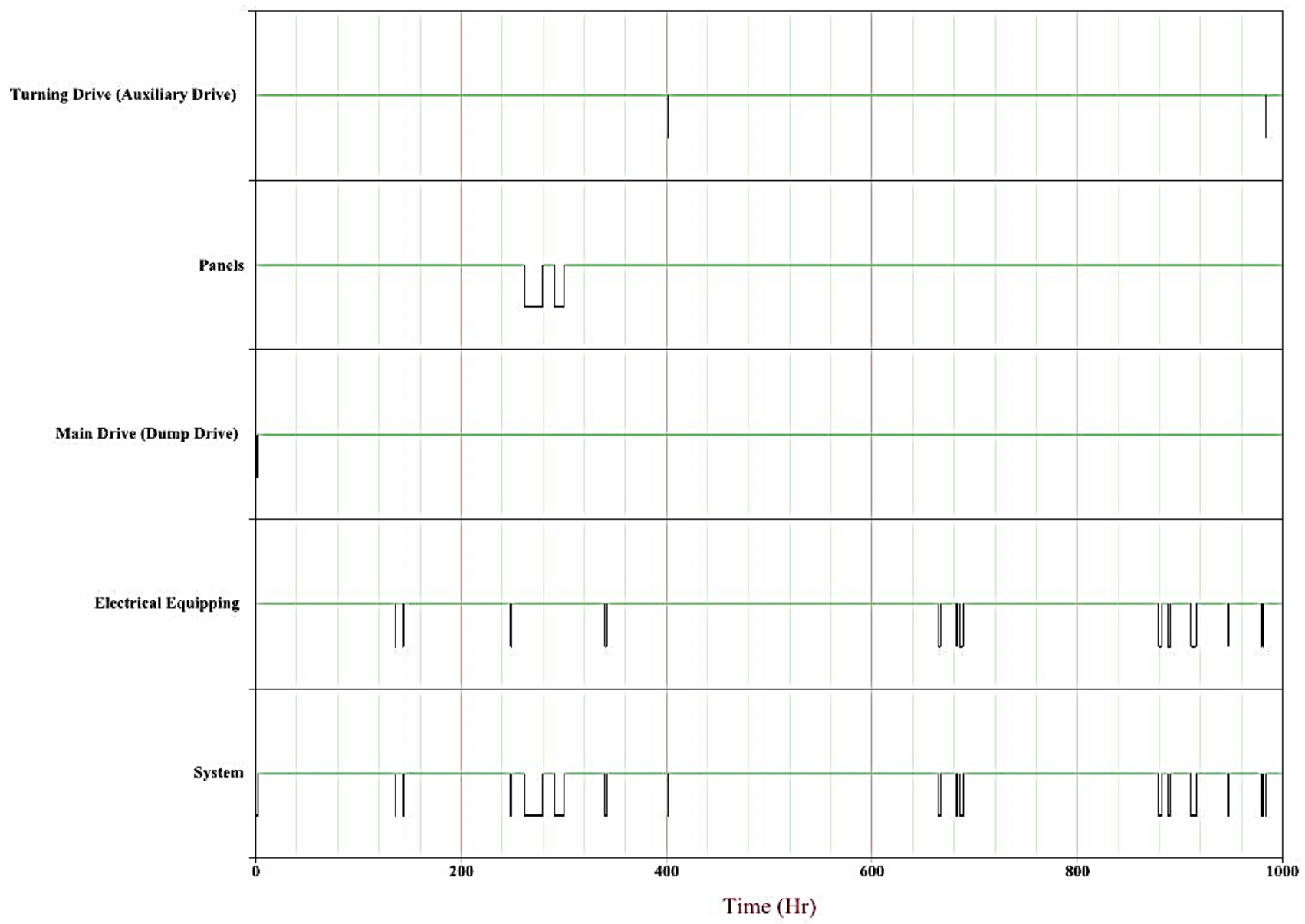

Figure 10: System and Block Up-Down.

Table 8: Block Summary

\begin{tabular}{|l|c|c|c|}
\hline Block Name & RS FCI & RS DECI & RS DTCI \\
\hline $\begin{array}{l}\text { Main Drive } \\
\text { (Dump Drive) }\end{array}$ & $7.81 \%$ & $7.81 \%$ & $7.62 \%$ \\
\hline $\begin{array}{l}\text { Turning Drive } \\
\text { (Auxiliary Drive) }\end{array}$ & $5.46 \%$ & $5.46 \%$ & $4.61 \%$ \\
\hline Panels & $9.45 \%$ & $9.45 \%$ & $20.61 \%$ \\
\hline Electrical Equipping & $77.28 \%$ & $77.28 \%$ & $67.16 \%$ \\
\hline
\end{tabular}

relative index indicating the contribution of the block to the system's failure (RS DTCI)) were used respectively, as demonstrated in Table 8.

As can be seen from the three indexes, electrical equipping has the largest effect with a value of $77.28 \%$. That is, maintenance tasks and inspections must focus more on this subsystem, while the main drive subsystem is the least important with a value of $7.81 \%$.

\section{Discussion}

The prime motivation for this study was to study the system's mean and point availability to analyze and simulate the availability of an Armored Face Conveyor in underground coal mining. Accordingly, data failure and repair time of an AFC system in the Tabas coal mining were collected. The findings indicate meaningful concepts in the analysis of the AFC machine in the Tabas underground coal mine using simulation. Since this machine directly affects the production capacity of the mine and in case of failure of the machine, it causes risks and disturbances. This situation hinders workers' safety and productivity. Despite the efforts of the mine managers, some national situations like the low price of coal or labor salary reduce economic standards. Moreover, sanctions cause a lack of accessibility to updated technology and equipment, as well as spare parts, thus further decreasing the performance operation. As a consequence, this causes a decrease in the production cycle, performance time, and an increase in production costs. This simulation was accomplished for about $210000 \mathrm{~h}$ using BlockSim software in each subsystem of the AFC machine. Based on the obtained results, mean availability (all events), standard deviation (mean availability), point availability (all events), reliability, MTTFF, MTBF (total time), MTBF (uptime), and uptime (h) have values of $0.960,0.013,0.95,0,23.605,46.204,44.357$, and 960.009 respectively, while total downtime $(\mathrm{Hr})$ was 39.99. RS FCI, RS DECI, RS DTCI metrics electrical equipping has the highest value, and hence, is the most important among the subsystems, whereas the main 


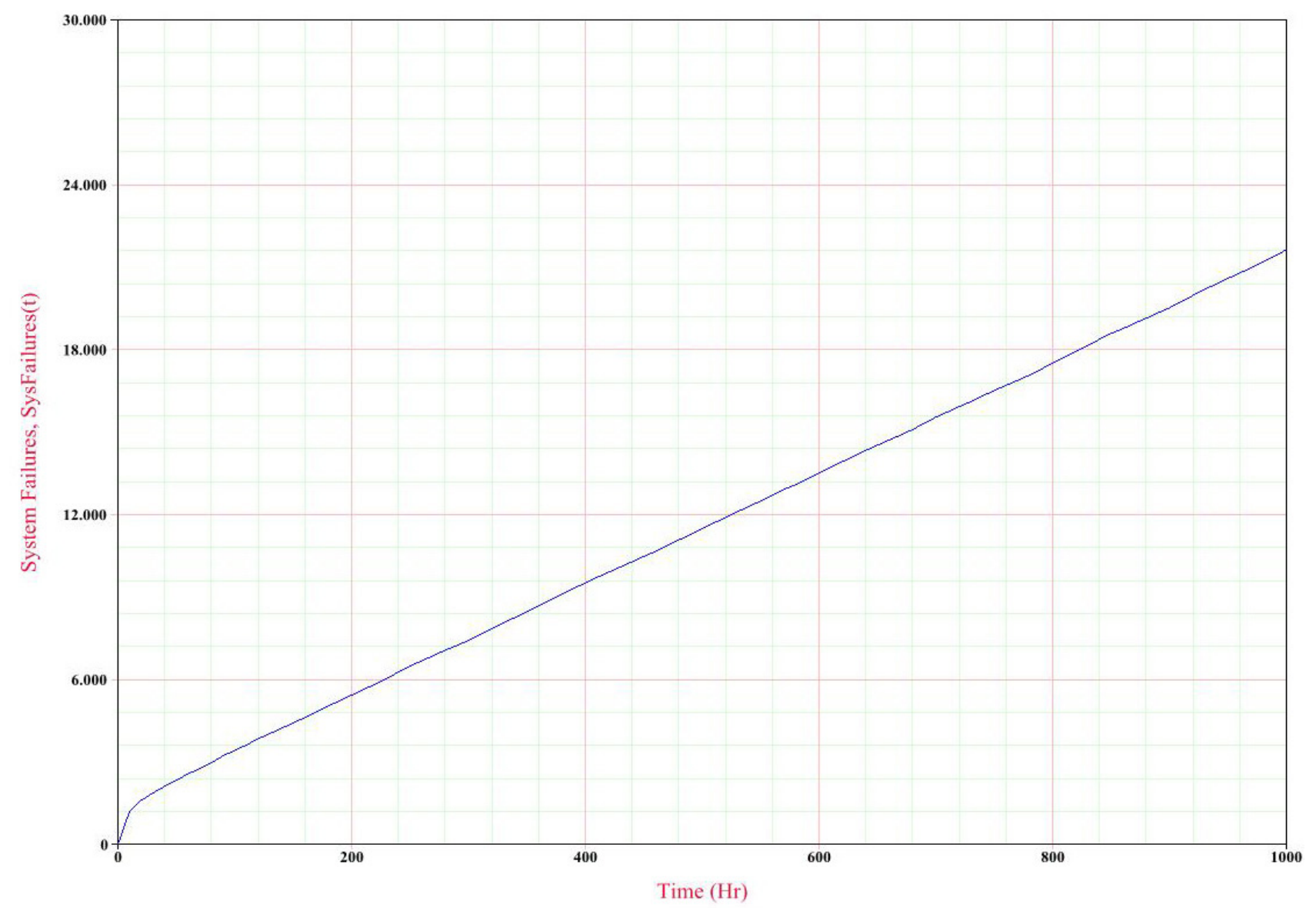

Figure 11: System failure of the AFC.

drive subsystem has the smallest value, and hence, in terms of failure, that subsystem is the least important.

As can be seen Figure 11, failures increase over time. This increase can have many reasons, for example, this device works three shifts, it is better to reduce the number of shifts to reduce downtime. Another reason for this increase is two operators for the machine, which is low due to the number of shifts. The response time for machine failure was very late, which can be the most important reason. As mentioned, sanctions prevent access to updated equipment, and when machine failure occurs, if the parts used in the repairs are not original parts, machine failures increase.

Generally, the study findings represent that this simulation is a useful scientific and systematic method for analyzing availability. Field experiences and observations indicate that the actual state of this mine is in accordance with the simulation model. Therefore, considering the results of this research, it can be concluded that this simulation has high validity for the assessment of the availability of the AFC machine in the coal mine.

\section{Conclusion}

In this paper, availability analysis and simulation of an AFC of the Tabas longwall coal mine in Iran were studied. For this aim, the system's mean and point availability of the AFC machine have been simulated. The following main conclusions can be drawn from this work:

- The MTBF (Total Time) for the AFC machine was $46.204 \mathrm{Hr}$, whereas the MTTFF (Hr) was $23.605 \mathrm{Hr}$.

- This problem indicates major problems in the system, such as insufficient technician skills, inadequate management, limited staff, and limited availability to spare parts, etc.

- RS FCI, RS DECI, RS DTCI electrical equipping have the largest effect. That is, maintenance tasks and inspections must focus more on this subsystem whereas the main drive subsystem is the least important.

- Failures increase over time.

Generally, the reliability and maintainability implementation is necessary, because this causes input engineers and managers to further improve their performance management and the maintenance policy of the AFC machine such as spare parts management, strategy of maintenance, decreasing the time of delivery, etc. The aim is to optimize the function of the AFC machine to the highest reliability, thus developing its availability, efficiency, and performance. 


\section{References}

Agrawal, A. K., Murthy, V. M. S. R., and Chattopadhyaya, S. (2019): Investigations into reliability, maintainability and availability of tunnel boring machine operating in mixed ground condition using Markov chains. Engineering Failure Analysis, 105, 477-489.

Ataei, M., and Masir, R. N. (2020): A fuzzy DEMATEL based sustainable development index (FDSDI) in open pit mining-a case study. Rudarsko-geološko-naftni zbornik, 35, 1.

Barabady, J. (2005): Reliability and maintainability analysis of crushing plants in Jajarm Bauxite Mine of Iran. In Annual Reliability and Maintainability Symposium, IEEE, 109-115.

Barabady, J., and Kumar, U. (2007): Availability allocation through importance measures. International Journal of Quality \& Reliability Management, 24, 643- 257.

Barabady, J., and Kumar, U. (2008): Reliability analysis of mining equipment: A case study of a crushing plant at Jajarm Bauxite Mine in Iran. Reliability engineering \& system safety, 93, 4, 647-653.

Beeson, S., and Andrews, J. D. (2003): Importance measures for noncoherent-system analysis. IEEE Transactions on Reliability, 52, 3, 301-310.

Brodny, J., Alszer, S., Krystek, J., and Tutak, M. (2017): Availability analysis of selected mining machinery. Archives of Control Sciences, 27.

Dai, H., Zhang, H., and Wang, W. (2015): A multiwavelet neural network-based response surface method for structural reliability analysis. Computer-Aided Civil and Infrastructure Engineering, 30, 2, 151-162.

Dhillon, B. S. (2008): Mining equipment reliability. Springer London, 57-70 p.

Elevli, S., Uzgoren, N., and Taksuk, M. (2008): Maintainability analysis of mechanical systems of electric cable shovels. Journal of Scientific and Industrial Research, 67, 4, 267-271.

Furuly, S., Barabadi, A., and Barabady, J. (2013): Reliability analysis of mining equipment considering operational environments-a case study. International J Perform Engineering, 9, 3, 287-94.

Hall, R.A., and Daneshmend, L.K. (2003a): Reliability Modelling of Surface Mining Equipment: Data Gathering and Analysis Methodologies. International Journal of Surface Mining, Reclamation and Environment, 17, 3, 139-155.

Hall, R.A., and Daneshmend, L.K. (2003b): Reliability and maintainability models for mobile underground haulage equipment. Canadian Institute of Mining, Metallurgy and Petroleum (CIM) Bulletin, 96, 1072, 159-165.

Harish Kumar, N. S., Choudhary, R. P., and Murthy, C. S. (2020): Model based reliability analysis of shovel-dumper system's mechanical failures used in the surface coal mine: a case study. Safety and Reliability, Taylor \& Francis, $1-15$.

Hoseinie, S. H., Ataei, M., Khalokakaie, R., Ghodrati, B., and Kumar, U. (2012): Reliability analysis of the cable system of drum shearer using the power law process model. Inter- national journal of mining, reclamation and environment, 26, 4, 309-323.

Hoseinie, S. H., Heydari, S., Ghodrati, B., and Kumar, U. (2020): Resilience measurement of longwall machinery. The Mining-Geological-Petroleum Engineering Bulletin (Rudarsko-geološko-naftni zbornik), 35, 3.

IEC 60050 - International Electro technical Vocabulary - Details for IEV number 191-02-06 (2014): reliability (performance).

IEC 60050 - International Electro technical Vocabulary - Details for IEV number 191-02-07 (2014): maintenance support performance.

Kumar, U., and Huang, Y. (1993): Reliability analysis of a mine production system-a case study. In Annual Reliability and Maintainability Symposium 1993 Proceedings, IEEE, 167-172.

Kumar, U., and Klefsjö, B. (1992): Reliability analysis of hydraulic systems of LHD machines using the power law process model. Reliability Engineering \& System Safety, $35,3,217-224$.

Li, Z. S. (2012): Reliability engineering. Journal of Quality Technology, 44, 4, 394.

Mena, R., Zio, E., Kristjanpoller, F., and Arata, A. (2013): Availability-based simulation and optimization modelling framework for open-pit mine truck allocation under dynamic constraints. International Journal of mining science and Technology, 23, 1, 113-119.

Naghiloo, A., Farzaneh, H., Shahabi, H. R., Assadi, M. K. H., and Dashti, M. (2011): Using a developed PM in order to optimize the production productivity in a cement industry. Journal of Applied Sciences and Environmental Management, 15, 2.

Pandey, P., Mukhopadhyay, A. K., and Chattopadhyaya, S. (2018): Reliability analysis and failure rate evaluation for critical subsystems of the dragline. Journal of the Brazilian Society of Mechanical Sciences and Engineering, 40, 2, 50.

Rahimdel, MJ., Ataei, M., Khalokakaei, R., and Hoseinie, SH. (2013): Reliability-based maintenance scheduling of hydraulic system of rotary drilling machines. International Journal Min Science Technology. 23, 5, 771-5.

Rahimdel, M. J., Ataei, M., and Ghodrati, B. (2020): Modelling and simulation approaches for reliability analysis of drilling machines. Journal of the Institution of Engineers (India): Series C, 101, 1, 125-133.

Razzaghzadeh, R., Shakoor Shahabi, R., and Nouri Qarahasanlou, A. (2019): Analysis of reliability and maintainability for multiple repairable units (Case study: Sungun copper mine). Journal of Mining and Environment, 10, 4, 1045-1059.

Stapelberg, R. F. (2009). Handbook of reliability, availability, maintainability and safety in engineering design. Springer Science \& Business Media, 539 p.

Vagenas, N., Runciman., N. and Clément, S.R. (1997): A methodology for maintenance analysis of mining equipment. International Journal of Surface Mining, Reclamation and Environment, 11, 1, 33-40.

Vayenas., N. and Wu, X. (2009): Maintenance and reliability analysis of a fleet of load haul-dump vehicles in an underground hard rock mine. International Journal of Mining, Reclamation and Environment, 23, 3, 227-238. 


\section{SAŽETAK}

\section{Simulacija dostupnosti i analiza rada oklopnoga transportera u širokočelnome rudarenju}

Sustavi proizvodnje ugljena u rudnicima vrlo su složeni, stoga je i popravak opreme skup. Kvar sustava uzrokovat će smetnje kao što je nedostupna oprema, smanjeno vrijeme rada, povećani troškovi proizvodnje i smanjene performanse opreme. Stoga je nužno da se dostupnost industrije ugljena razmatra više nego ikad. U tu svrhu 29 mjeseci prikupljani su podatci o kvaru stroja tipa oklopljenoga širokočelnoga transportera iz rudnika ugljena Tabas. Izračunane su opisna statistika, trendovi i test serijske korelacije podataka. Zatim su simulirane srednje vrijednosti i dostupnost bodova u sustavu. Na temelju rezultata prosječna dostupnost (svi događaji) i dostupnost točke (svi događaji) na 360 ooo h iznose $96 \%$ odnosno $95 \%$. Prosječno je vrijeme do prvoga kvara (MTTFF) transportnog stroja oko 23,61 h. U trima metričkim vrijednostima, ReliaSoft indeksu kritičnosti kvara, ReliaSoft indeksu kritičnosti pada sustava i ReliaSoft indeksu kritičnosti zastoja, električno opremanje ima najveći učinak, dok je glavni pogonski podsustav najmanje važan. Utvrđeno je da analiza dostupnosti kontrolira upravljanje operacijama i poboljšanja u kvaliteti, učinkovitosti i izvedbi linije.

\section{Ključne riječi:}

oklopljeni širokočelni transporter; pouzdanost; održivost; simulacija dostupnosti

\section{Author's contribution}

Raziye Norouzi Masir (Ph.D. Candidate): initialized the idea, completed a literature review, and participated in all work stages, such as gathering the data on the diurnal operation and production reports of supervisors and the maintenance reports of the systems. Mohammad Ataei (Full Professor): analyzed the data collected, managed the whole process and supervised it from the beginning to the end. Farhang Sereshki (Full Professor): analyzed data calculations using Minitab software. Ali Nouri Qarahasanlou (assistant Professor): calculated data using BlockSim software. 